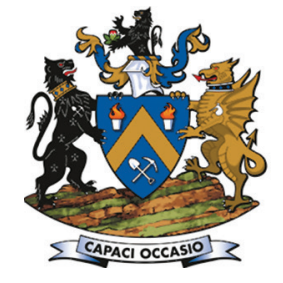

Affiliation:

1 University of Pretoria, Pretoria South Africa.

Correspondence to:

E. Du Toit

Email:

elda.dutoit@up.ac.za

\section{Dates:}

Received: 14 Sep. 2020

Revised: 11 Dec. 2020

Accepted: 11 Jan. 2021

Published: March 2021

How to cite:

Du Toit, E. and Delport, P.W.J. 2021

Supplementary Mineral

Resources and Mineral Reserves

Reports: Readability and textual

choice.

Journal of the Southern African

Institute of Mining and Metallurgy,

vol. 121, no. 3, pp. 119-128.

DOI ID:

http://dx.doi.org/10.17159/24119717/1381/2021

ORCID

E. du Toit

https://orchid.org/0000-0001-

8386-7969

P.W.J. Delport

https://orchid.org/0000-00034512-1204

\title{
Supplementary Mineral Resources and Mineral Reserves Reports: Readability and textual choice
}

\author{
E. Du Toit ${ }^{1}$ and P.W.J. Delport ${ }^{1}$
}

\begin{abstract}
Synopsis
Investing in a mining venture can be risky and stakeholders need transparent, unbiased reports to understand the Mineral Resources and Mineral Reserves a mining company holds. Readability and textual choice can be used consciously to manipulate perceptions, or it can be done unconsciously. This exploratory study investigates the readability and textual choice of supplementary Mineral Resources and Mineral Reserves Reports of companies listed on the Johannesburg Stock Exchange. The results indicate that narrative manipulation occurs in these reports through word choices that make the reports difficult to read, as well as specific narrative selections. This reduces the informational value of the reports. The results of the study will be useful to various stakeholders, such as mining company management, investors, investment specialists, financial analysts, and even employees and the general community, who all use these reports to make important decisions. It is also useful for the preparers of the Mineral Resources and Mineral Reserves Reports, Competent Persons, and other technical specialists to be aware of readability and that certain textual choices can affect the interpretation of these reports. It is recommended that bodies such as the JSE and the SAMREC and SAMVAL Code committees consider adding a plain language requirement to regulations, guidelines, and codes to ensure transparent, unbiased, and objective reports.
\end{abstract}

\section{Keywords}

Corporate reporting, Mineral Resources. Mineral Reserves, narrative style, readability.

\section{Introduction}

Mining is an inherently risky business. Several factors are at play, such as the geological, technical, environmental, social, political, and economic uncertainties at the different stages in the life-cycle of a mining venture (Noppé, 2014). International codes for the reporting of Mineral Resources and Mineral Reserves stipulate the minimum requirements for the Mineral Resources and Mineral Reserves Statement in the Competent Person's (CP's) Report, and thus the information that informs any published summary of Mineral Resources and Mineral Reserves, such as may be found either in the Integrated Annual Report (IAR) or in a supplement to the IAR. However, in narrative disclosures, there is always a measure of subjectivity and this is likely to be the case also in the narrative sections of the summarized information.

The term 'Mineral Resources and Mineral Reserves Report' will be used to refer to a supplementary document produced by a company as part of its IAR and which forms part of the corporate reports made available to a variety of stakeholders who depend on the information for decision-making. These reports are often summarized from CPs Reports (in the case of new listings and material change reports) or from a host of internal data and information in the case of established mining companies preparing their IARs.

The most frequent users of corporate reports are investors and investment advisors, but employees, creditors, and local communities may also have an interest in the operations, Mineral Resources, and Mineral Reserves of a mining company. Recently, members of a small rural community won a court case against a mining company after the community claimed that information about the mine's activities had been withheld (Field, 2020). This case was about mining right information specifically, but the same situation can happen with any mining activity, from prospecting rights to changes in Mineral Resources and Mineral Reserves and the resulting mining activities. Investors and investment advisors may need more detailed and advanced information about a mining company, but other stakeholders such as local (often rural) communities should not be disregarded.

Dominy, Noppé, and Annels (2002) call for a requirement that Mineral Resources and Mineral Reserves Reports should comply with high-quality interpretation. It is imperative that the reports not only make use of the best quality numerical data, but should also be presented in a way that considers 


\section{Supplementary Mineral Resources and Mineral Reserves Reports: Readability and textual choice}

the goals and background of the company's various stakeholders. Even though the users of corporate reports are most often highly educated individuals, one cannot assume that this is the case for all and not everyone can be expected to be an expert in the technical aspects of a mining venture. The US Securities and Exchange Commission (SEC) made strides when it not only published the Plain English Handbook for creating clear corporate disclosures, but also prescribed a plain English requirement in its SEC S-K 1300 regulation for mining disclosures. This was a first step in recognizing that disclosures are often written in a way that hampers understanding and decision-making for all stakeholders (SEC, 1998). In response to the SEC Plain English Handbook, Montevirgen (2016) emphasises that word choice can significantly affect reading efficiency, that readability presents opportunities for competitive advantage, and that readability encourages trust.

The Johannesburg Stock Exchange (JSE) Listings Requirements Section 12, Clause 12.2 stipulates that the CP's Report, and thus any summarized Mineral Resources and Mineral Reserves Report of a listed mining company, has to comply with the requirements of the South African Code for the Reporting of Exploration Results, Mineral Resources and Mineral Reserves (SAMREC) and the South African Code for the Reporting of Mineral Asset Valuation (SAMVAL), also known as the SAMCODES. These Codes provide guidance on how Mineral Resources and Mineral Reserves must be estimated, valued, and reported. However, the Codes do not make any mention of the language companies should use when they report on Mineral Resources and Mineral Reserves. The JSE Listings Requirements mention the use of plain language in two places, namely where index disclosure transparency is discussed and in an Appendix to Schedule 16, related to conflicts of interest. Unlike the SEC, which stipulates how companies should create clear disclosure documents, the JSE, SAMREC, and SAMVAL do not yet specifically prescribe the use of plain language nor require companies to avoid biased language. There are, however, talks about including the concept of plain language use in future versions of the SAMCODES, and Introductory and Advanced SAMCODES training courses already include references to plain language.

Noppé (2014) states that disclosures on Mineral Resources and Mineral Reserves should convey a balanced view of the opportunities and risks a project presents. Since reporting is for the benefit of various stakeholders, the information should be presented in a way that is accessible to all. Not all stakeholders are lawyers, accountants, or investment bankers (SEC, 1998), and it stands to reason that even fewer are CPs on a particular commodity. It is important to note that this paper does not endorse the idea of 'dumbing down' information, but as the SEC Plain English Handbook explains, a complicated concept can be written in a way that ensures someone who is not an expert in the field can still understand (SEC, 1998).

Interested parties require transparent reports, i.e. reports that are unbiased in their reporting, to understand the Mineral Resources and Mineral Reserves the company holds (Dominy, Noppé, and Annels, 2002). Although CPs use diverse ways to estimate Mineral Resources and Mineral Reserves, the classification criteria and methods used must be clearly described, so that the stakeholder can make informed decisions. Unreadable or biased language in these reports can lead to incorrect interpretations by stakeholders. Noppé (2014) gives examples of the far-reaching effects that misinterpretation of a final
Mineral Resources and Mineral Reserves estimation could have. However, apart from actual mistakes in a Mineral Resources and Mineral Reserves Report, there are other 'softer' factors that can also play a role. The first is readability. An analysis of the readability of IARs, showed that public corporate reports are often only accessible by a significantly specialised audience (du Toit, 2017), whereas the reports are in fact available to and meant for a wide stakeholder audience. A lack of readability, intentional or unintentional, can affect the informational value of Mineral Resources and Mineral Reserves Reports as part of the corporate report portfolio of a listed company. In addition, specific textual choices can lead to the misinterpretation of a report, as can be seen in Laskin (2018), who found that companies frame their reports in a way that manipulates stakeholder impressions. Textual choice in this sense refers to the use of specific words to convey a particular message, for example the use of optimistic words to hide negative news. The use of a specific tone can thus cause bias in the impression it creates of the company. A prime example is Steinhoff NV, which used excessively optimistic language in its IAR shortly before the company was found out for committing fraud (this is based on an analysis of the Steinhoff IARs using specialized software). The aim of a corporate report of any kind is to present an unbiased view of the company, its operations, and its performance. Even though the Mineral Resources and Mineral Reserves Report or sections thereof appearing in the IAR is checked by a CP before publication for factual correctness, poor readability or use of a specific narrative tone may not raise concern.

Readability and textual choice can be used consciously to manipulate, or unconsciously. However, if a report preparer and/ or CP pays specific attention to these matters before publication of the report, it can improve the transparency (i.e., objectivity) and ultimate the usefulness of supplementary Mineral Resources and Mineral Reserves Reports. The research question investigated in this study can be stated as follows:

What constitutes readability of supplementary Mineral

Resources and Mineral Reserves Reports, and what specific textual choices are applied by the preparers thereof?

This exploratory study investigates the readability and textual choice of Mineral Resources and Mineral Reserves Reports (made available as supplementary reports to the IARs) of listed mining companies in South Africa. The purpose is to investigate the readability and narrative choice of the reports as they are made available to a variety of stakeholders.

Firstly, the results of the study will be useful to mining company management, investors, investment specialists, and analysts, who all use these reports to make important decisions about a company's financial prospects. Secondly, the results show preparers of the Mineral Resources and Mineral Reserves Reports that readability and certain textual choices can cause bias in the report. The study acts as a reminder that not all stakeholders are sophisticated readers or technical experts on the activities of a mining venture. Finally, the study indicates to bodies such as the JSE, and the SAMREC and SAMVAL Code committees that it may be necessary to improve regulations, reporting guidelines, and reporting codes even further by including recommendations for plain language and even suggestions on the use of certain textual choices.

The rest of the paper is structured as follows: An overview of the literature is followed by the method employed in the study. The results of the analyses are then presented, followed by a discussion and conclusions. 


\section{Supplementary Mineral Resources and Mineral Reserves Reports: Readability and textual choice}

\section{Literature review}

The theoretical foundations of this study are the stakeholder and legitimacy theories. A company has responsibilities towards a wide variety of stakeholders, such as investors, employees, suppliers, the government, and many other interested and affected parties (stakeholders) have an interest in the performance of a company (Freeman, 1984). Corporate reports are not only prepared for the benefit of stakeholders as per stakeholder theory; they are also part of legitimacy theory, seeing that companies use such reports to legitimize their actions (Barkemeyer et al., 2014; Böhling and Murguía, 2014; Camilleri, 2019; Criado-Jiménez et al., 2008; Daub, 2007; de Villiers, Low, and Samkin, 2014; Maubane, Prinsloo, and van Rooyen, 2014; O'Donovan, 2002).

However, where reporting is concerned, a subset of legitimacy theory, namely impression management theory, should also be considered. Impression management theory states that companies present their reports in a way that aims to create a specific impression of the company and its performance, thus manipulating the perceptions of stakeholders to obtain legitimacy (Cho, Michelon, and Patten, 2012; Criado-Jiménez et al., 2008; Daub, 2007; Diouf and Boiral, 2017; Emel, Makene, and Wangari, 2012; Hooghiemstra, 2000; Jones et al., 2017; MerklDavies and Brennan, 2007; O'Donovan, 2002; Stacchezzini, Melloni, and Lai, 2016). Impression management may involve, for example, the use of poor readability to hide poor performance (Courtis, 2004; Diouf and Boiral, 2017; Hasan, 2018; MerklDavies and Brennan, 2007; Rutherford, 2003; Smeuninx, de Clerck, and Aerts, 2020) or writing reports in a specific tone, such as optimistic language, to give the impression that the company is doing well (Fonseca, 2010).

Corporate reports, especially reports that are mostly narrative, are frequently criticised for a lack of quality and reliability (Cho et al., 2012; Diouf and Boiral, 2017; Emel et al., 2012), being difficult to read (Smeuninx et al., 2020), and for being marketing tools for legitimization or impression management (Diouf and Boiral, 2017; Merkl-Davies and Brennan, 2011; Ngwakwe and Mtsweni, 2016; O'Donovan, 2002; Stacchezzini et al., 2016). There may be a disconnect between the goals and competencies of the preparers of Mineral Resources and Mineral Reserves Reports and those who use them. The CPR, which includes the estimation and valuation of Mineral Resources and Mineral Reserves, has to be prepared by a 'Competent Person' (SAMREC, 2016) and any valuation conducted by a Competent Valuator (CV) (SAMVAL, 2016). The information in the supplementary Mineral Resources and Mineral Reserves Report is based on this information, prepared by report writers, and checked by a $\mathrm{CP} \backslash$ and $\mathrm{CV}$ for accuracy. The requirements for a $\mathrm{CP}$ and a $\mathrm{CV}$ do not stipulate any financial, accounting, or investment knowledge, even though the report may be prepared for use by investors, analysts, management accountants, and other persons who operate in the financial domain. It makes sense that Mineral Resources and Mineral Reserves Reports that lack general readability and make use of specific textual choices can potentially be a means to manipulate the perceptions of readers. For such reports to be useful for financial professionals and others, they need to be transparent and clear in their meaning, without obfuscating the facts, whether intentionally or unintentionally. It is thus necessary for finance and mining specialists to work together to ensure that all parties can benefit equally from the effort that goes into a Mineral Resources and Mineral Reserves Report.

There is increasing interest in textual analysis of corporate reports (Hasan, 2018). Textual analysis can be used to analyse readability (Bonsall et al., 2017; Li, 2008) and the tone used in a report. Both readability and tone are used by companies to manipulate stakeholder impressions (Hasan, 2018; Rutherford, 2003). The purpose of any corporate report is the disclosure of information for decision-making and to that end stakeholders prefer short, focused, and readable reports (Caglio, Melloni, and Perego, 2020; Lambert, Leuz, and Verrecchia, 2007; Smeuninx et al., 2020; Zhou, Simnett, and Green, 2017). Several studies have investigated the readability of the narrative sections of corporate reports (Bonsall et al., 2017; Bonsall and Miller, 2017; du Toit, 2017; Hasan, 2018; Li, 2008; Loughran and McDonald, 2014, 2016; Smeuninx et al., 2020) and most found the narrative sections of such reports to be unclear. Studies have also investigated the textual tone of narrative disclosures, especially the presence of optimistic and 'certainty' words (Arena, Bozzolan, and Michelon, 2015; Cho, Roberts, and Patten, 2010; Davis, Piger, and Sedor, 2006; Hassan, 2019; Ober et al., 1999).

The conclusion derived from the literature is that a report can be considered to be poor quality if it is difficult to read (Bonsall et al., 2017; Caglio et al., 2020; Loughran, and McDonald, 2016), and if it is biased through using a specific narrative tone (Huang, Teoh, and Zhang, 2014).

\section{Method}

The study uses a limited sample of supplementary Mineral Resources and Mineral Reserves Reports obtained from the websites of JSE-listed mining companies over a period of two years, 2018 and 2019. Of the 29 listed companies, 16 issued a supplementary Mineral Resources and Mineral Reserves Report in 2018, and 17 in 2019. The sample thus consists of 33 supplementary Mineral Resources and Mineral Reserves Reports. The researchers decided to consider, for this first exploratory study, the stand-alone reports separately and not supplement them with extracts from Mineral Resources and Mineral Reserves sections that appear within other corporate reports such as the IAR. These reports were analysed for readability and textual choice using software, namely Readability Studio 2019 and Diction 7.1 .3 , respectively.

Software is recommended for readability analyses because it is objective, easy to use, and understandable (Clatworthy and Jones, 2001; Courtis, 1998; Eugene Baker, Kare, 1992; Klare, 1974). Because readability tests are used for different purposes, the developers of Readability Studio 2019 by Oleander Software indicate which tests are most suitable for the task at hand. The Flesch Reading Ease, Flesch-Kincaid, and Gunning-Fog measures are recommended for technical reports. These three readability measures are calculated as follows:

> The Flesch Reading Ease is calculated as [206.835 0.846 (number of syllables per 100 words) - 1.015 (average sentence length in words)].

> The Flesch-Kincaid measure is calculated as $[(0.39 \times$ average sentence length $)+(11.8 \times$ average syllables per word) - 15.59].

$>$ The Gunning Fog Index is calculated as [0.4 $\times$ (average number of words per sentence + percentage of 'hard' words in the passage)]. In this context, 'hard' words are defined as polysyllabic words. 


\section{Supplementary Mineral Resources and Mineral Reserves Reports: Readability and textual choice}

In addition to these tests, the readability software also measures the length and difficulty of the words used in the reports, as well as the use of passive sentences and so-called 'wordy' items. A wordy item is defined by Readability Studio 2019 as an unnecessarily long phrase that could be replaced with a shorter word or term, for example 'a case in point', 'a large number of', or 'a majority of'.

For narrative strategy, this study makes use of Diction 7.1.3 and its corresponding built-in word lists. Diction 7.1.3 measures the textual characteristics of text to determine if a specific linguistic strategy is used (Hart, 2000; Hart and Carroll, 2013). The broad narrative strategy categories are Certainty, Optimism, Activity, Realism, and Commonality (Hart, 2000; Laskin, 2018). A detailed table illustrating the types of words Diction considers in each category is included as an appendix to this paper.

The result from a textual analysis is a score based on the frequency that a narrative choice occurs. These scores are measured against a predetermined standard as specified by the software developer and built into the software (Alexa and Zuell, 2000; Hart, 2000; Hart and Carroll, 2013). For this study, the text is measured against the Corporate Financial Reports normative base. This means the reports analysed for this study were measured based on the narrative sections of corporate reports, in South Africa the IARs. A software application for narrative analysis has the benefit of inherent stability, clear coding rules that allow for comparability, coder reliability, and the ability to process large volumes of text (Ober et al., 1999).

The results from the readability tests and narrative analysis are analysed in terms of descriptive statistics to create an initial frame of reference for future studies using more advanced statistical techniques.

\section{Results}

Analysis of a sample of supplementary Mineral Resources and Mineral Reserves Reports shows a general lack of readability and specific narrative tones. Table I depicts the basic descriptive statistical results for the readability of the 33 supplementary Mineral Resources and Mineral Reserves Reports. The results were averaged rather than summed so that the values correspond to the readability measure interpretation scales. The use of average values assumes that the measures for the separate items use the same response format and have equivalent error score variances (Bedeian, 2014). Since standard tests are applied to all the Mineral Resources and Mineral Reserves Reports, these assumptions are confirmed for the variables considered in this study.

The Flesch-Kincaid measure refers to the grade (or education) level a reader needs to understand the material (Li, 2008). The results from the Flesch-Kincaid readability measure show a range from 12.80 to 19.00 , with a mode of 19.00 (the mode is the score that occurred most often). This indicates that the Mineral Resources and Mineral Reserves Reports are Very Difficult to read and only understandable by university graduates or postgraduate students (i.e. individuals with between 13 and 19 years' education, but most often at least 19 years). Even though investors and investor advisors usually hold a tertiary qualification, they are not necessarily experts in mining and geology. In addition, other stakeholders who may not possess a tertiary qualification may have a legitimate interest in the operations of the company and should not be ignored. A further implication of poor readability in the South African context is that English is a second or third language for the majority of the population. South Africa has 11 official languages and English is only the sixth most common home language (8.1\%), although it is the second most common language (16.6\%) spoken outside the home (isizulu ranks first with 25.1\%) (South Africa, 2019). Readability tests originate from countries where English is the first (or sometimes only) language. Thus a text considered by a readability test to be readable by someone with 15 years of education may require even further or more specialised education in South Africa.

The results from the Flesch Reading Ease formula range from 5.00 to 47.00 , with a mode of 31.00 . The lower this value, the more difficult the text is considered to be (Flesch, 1979). The 30 to 50 standard range for Flesch Reading Ease is indicative of Difficult material that is appropriate for individuals with an undergraduate degree (e.g., academic literature). The zero to 30 standard range indicates Very Difficult material, which is appropriate for individuals with a postgraduate degree (e.g. scientific material). The reading ease of Mineral Resources and Mineral Reserves Reports differs widely but is within the category of Difficult to Very Difficult, similar to the Flesch-Kincaid measure.

The Gunning Fog Index formula indicates that short sentences written in plain English score better than long sentences written in complicated language. The ideal Fog readability score is 7 or 8 . The score of between 10.20 and 16.40 and mode of 15.00 indicate again that the Mineral Resources and Mineral Reserves Reports are too hard for most people to read.

Readability tests are ideal as initial tests of readability. For example, the tests do not consider that not all multi-syllabic words are necessarily difficult. In corporate reports one cannot realistically use only simple words. However, an excessive number of difficult words can indicate potential readability issues.

In addition to the standard readability measures, the percentage of complex and long words in the Mineral Resources

Table I

Readability results: descriptive statistics

\begin{tabular}{|c|c|c|c|c|c|c|}
\hline & Mean & Mode & SD & Range & Min. & Max. \\
\hline Flesch-Kincaid & 16.09 & 19.00 & 2.19 & 6.20 & 12.80 & 19.00 \\
\hline Flesch Reading Ease & 30.15 & 31.00 & 9.89 & 42.00 & 5.00 & 47.00 \\
\hline Gunning Fog & 13.56 & 15.00 & 1.92 & 6.20 & 10.20 & 16.40 \\
\hline$\%$ complex words & 0.24 & $23.10 \%$ & 0.02 & 0.08 & 0.20 & 0.27 \\
\hline$\%$ of long words & 0.42 & $38.60 \%$ & 0.02 & 0.10 & 0.37 & 0.48 \\
\hline Passive voice & 1416.39 & 117.00 & 932.60 & 3336.00 & 117.00 & 3453.00 \\
\hline Wordy items & 16.09 & 19.00 & 2.19 & 6.20 & 12.80 & 19.00 \\
\hline \multicolumn{7}{|l|}{$N=33$} \\
\hline
\end{tabular}




\section{Supplementary Mineral Resources and Mineral Reserves Reports: Readability and textual choice}

and Mineral Reserves Reports is significant. The text in the reports contains several passive voice sentences, which in essence are harder to follow than sentences written in the active voice and can be used to hide a negative message due to their being inherently more difficult to read (Sydserff and Weetman, 1999). This is a generalization, and passive voice is not necessarily used as a means to manipulate a text, but it is something to avoid and look out for as it does affect readability.

The Mineral Resources and Mineral Reserves Reports contain significant numbers of wordy items that can be replaced by simpler words or phrases. The following are examples of wordy items that were highlighted by the software. These indicate narrative that is difficult to read and which can be stated in simpler terms without infringing on the meaning of the text or 'dumbing it down'.

\begin{tabular}{|l|l|}
\hline abbreviated & shortened \\
accomplished & did, done \\
actually & really \\
alternative & choice \\
amendment & change \\
annually & yearly \\
as a consequence of & because, because of, from, since \\
as a result of & because of, due to, following \\
as well as & and, also \\
at the time & when \\
by means of & by, with, from, in, over, through \\
commencement & start \\
frequently & often \\
however & but \\
in terms of & as for \\
is in compliance with & complies with \\
necessary & needed \\
obtained & got \\
previous & earlier, past \\
previously & before, earlier \\
prior to & before \\
required & needed \\
result in & lead to \\
taking into account & considering \\
\hline
\end{tabular}

Other examples of readability issues in specific sentences or sections in the Mineral Resources and Mineral Reserve Reports are as follows:

The use of simpler terms:

On the basis of seam thickness and coal quality...

Based on seam thickness and coal quality...

Using the active voice rather than passive voice:

Additional exclusive Mineral Resources of 1.6 billion tonnes at a grade of $0.37 \% \mathrm{TCu}$ are also declared...

The company also declared more exclusive Mineral Resources of 1.6 billion tonnes at a grade of $0.37 \% \mathrm{TCu} .$.

These are only a few examples. In a lengthy document of more than 100 pages, persistent use of unnecessary or difficult words where simpler ones are available can result in an overall unreadable text.

For the textual analysis, Diction 7.1.3 was used to measure the narrative tone in the Mineral Resources and Mineral Reserves Reports using pre-defined built-in word lists that represent a specific narrative style, as shown in the table in the Appendix. Table II summarizes the descriptive statistics for narrative tone.
Diction analyses text for certain narrative choices. There are five main categories: Certainty, Optimism, Activity, Realism, and Commonality. As a main category, the Certainty aspect (mean = 44.89; $\mathrm{SD}=4.90$, mode $=29.66$ ) refers to language indicating purpose, inflexibility, completeness, and a tendency to speak with authority. Under Certainty, the results show high levels of the use of words relating to Insistence (mean $=124.45 ; \mathrm{SD}=60.61$, mode $=24.27$ ), which refers to an ordered environment, and Numerical Terms (mean $=93.04 ; \mathrm{SD}=67.61$, mode $=12.69$ ), which is to be expected, due to the reports being quantitative in nature. The Optimism main category (mean $=49.52$; $\mathrm{SD}=1.48$, mode $=50.17$ ) refers to language that endorses a person, group, concept, or event or that highlights their positive attributes. The use of Inspiration type words (mean $=2.58 ; \mathrm{SD}=2.41$, mode $=0.16$ ) was the most prominent part of the Optimism score. In the Activity main category (mean $=48.00 ; \mathrm{SD}=1.62$, mode $=$ 51.16), which refers to language featuring movement, change, the implementation of ideas, and the avoidance of passivity, words relating to Accomplishment (mean $=9.91 ; \mathrm{SD}=4.93$, mode $=7.91$ ) and Communication (mean $=5.59 ; \mathrm{SD}=3.53$, mode $=2.99$ ) stood out. The Realism main category (mean = $46.80 ; \mathrm{SD}=1.86$, mode $=54.78$ ) relates to language describing tangible, immediate, recognizable matters that affect people's everyday lives. The most prominent categories of words under Realism were Spatial Terms (mean $=11.06 ; \mathrm{SD}=7.43$, mode $=$ 1.08), which makes sense in the context of mining operations, and Concreteness $($ mean $=20.31 ; \mathrm{SD}=10.32$, mode $=2.66$ ), which relates to tangible objects. The mean values for Temporal Terms and Complexity were not exceptionally high, but the mode values were (3.23 and 5.47 respectively). The main category of Commonality $($ mean $=48.99 ; \mathrm{SD}=1.75$, mode $=45.70$ ) refers to language highlighting the values of a group. The most prominent word categories under Commonality were Centrality (mean = $6.31 ; \mathrm{SD}=4.57$, mode $=0.63)$, which relates to core values, and Cooperation $($ mean $=4.86 ; \mathrm{SD}=3.49$, mode $=6.69)$, which refers to interactions among people.

A summary of the main categories of textual choice (as shown in Table III) indicates that the Mineral Resources and Mineral Reserves Reports tend to make extensive use of words relating to Optimism and Commonality, as shown by the mean scores for these categories. This can indicate an attempt to ensure that interested parties firstly get a positive and optimistic picture of the company's Mineral Resources and Mineral Reserves (Optimism), and secondly to create the impression that the company operates in an environment that emphasises the importance of core values (Commonality). If the mode values are considered (i.e., scores that occur most frequently for the companies) both Optimism and Commonality feature again, with Activity in addition, indicating the frequent use of words related to movement, change, and new ideas.

The output from Diction 7.1.3 does not provide specific examples of text that takes on a particular narrative tone. However, to illustrate how narrative tone can be used to manipulate impressions, the 2013 Mineral Resources and Mineral Reserves Report of a prominent company that was affected by the Marikana massacre of 2012 was analysed. The results from the narrative analysis show similar high scores for especially Optimism (highlighting positive attributes) and Commonality (highlighting the values of a group). Given the effect that the Marikana event had on this company's profile, it makes sense that the reports published subsequently should try to convince 


\begin{tabular}{|c|c|c|c|c|c|c|}
\hline & Mean & Mode & SD & Range & Min. & Max. \\
\hline Certainty & 44.89 & 29.66 & 4.90 & 22.13 & 29.66 & 51.79 \\
\hline Tenacity & 11.09 & 1.29 & 10.04 & 40.31 & 1.29 & 41.60 \\
\hline Levelling terms & 3.25 & 0.58 & 2.10 & 8.25 & 0.58 & 8.83 \\
\hline Collectives & 3.82 & 3.69 & 2.54 & 11.21 & 0.38 & 11.59 \\
\hline Insistence & 124.45 & 24.27 & 60.61 & 269.09 & 24.27 & 293.36 \\
\hline Numerical terms & 93.04 & 12.69 & 67.61 & 284.29 & 12.69 & 296.98 \\
\hline Ambivalence & 2.30 & 0.36 & 2.01 & 8.54 & 0.09 & 8.63 \\
\hline Self-reference & 2.54 & 0.20 & 4.26 & 17.58 & 0.05 & 17.63 \\
\hline Variety & 0.42 & 0.46 & 0.10 & 0.38 & 0.21 & 0.59 \\
\hline Optimism & 49.52 & 50.17 & 1.48 & 7.28 & 45.70 & 52.98 \\
\hline Praise & 1.72 & 0.00 & 1.53 & 5.54 & 0.00 & 5.54 \\
\hline Satisfaction & 0.23 & 0.00 & 0.30 & 1.07 & 0.00 & 1.07 \\
\hline Inspiration & 2.58 & 0.16 & 2.41 & 8.51 & 0.16 & 8.67 \\
\hline Blame & 0.39 & 0.00 & 0.70 & 3.66 & 0.00 & 3.66 \\
\hline Hardship & 1.11 & 0.13 & 0.94 & 3.65 & 0.04 & 3.69 \\
\hline Denial & 1.86 & 1.05 & 2.02 & 7.97 & 0.00 & 7.97 \\
\hline Activity & 48.00 & 51.16 & 1.62 & 6.77 & 45.00 & 51.77 \\
\hline Aggression & 0.64 & 0.00 & 0.50 & 1.73 & 0.00 & 1.73 \\
\hline Accomplishment & 9.91 & 7.91 & 4.93 & 24.27 & 3.89 & 28.16 \\
\hline Communication & 5.59 & 2.99 & 3.53 & 13.29 & 0.81 & 14.10 \\
\hline Motion & 0.17 & 0.00 & 0.28 & 1.24 & 0.00 & 1.24 \\
\hline Cognition & 7.38 & 0.43 & 5.18 & 19.60 & 0.43 & 20.03 \\
\hline Passivity & 2.88 & 0.76 & 2.47 & 11.00 & 0.59 & 11.59 \\
\hline Embellishment & 0.80 & 0.47 & 0.79 & 4.57 & 0.20 & 4.77 \\
\hline Realism & 46.80 & 45.78 & 1.86 & 8.17 & 43.80 & 51.97 \\
\hline Familiarity & 64.84 & 21.44 & 29.19 & 98.96 & 21.44 & 120.40 \\
\hline Spatial terms & 11.06 & 1.08 & 7.43 & 39.01 & 1.08 & 40.09 \\
\hline Temporal terms & 5.68 & 3.23 & 4.66 & 22.68 & 0.92 & 23.60 \\
\hline Present concern & 3.42 & 0.96 & 1.69 & 6.72 & 0.62 & 7.34 \\
\hline Human interest & 2.01 & 0.98 & 1.66 & 6.49 & 0.22 & 6.71 \\
\hline Concreteness & 20.31 & 2.66 & 10.32 & 35.67 & 2.66 & 38.33 \\
\hline Past concern & 1.42 & 0.02 & 1.28 & 5.16 & 0.00 & 5.16 \\
\hline Complexity & 4.78 & 5.47 & 0.66 & 2.50 & 3.36 & 5.86 \\
\hline Commonality & 48.99 & 45.70 & 1.75 & 8.50 & 45.70 & 54.20 \\
\hline Centrality & 6.31 & 0.63 & 4.57 & 23.49 & 0.63 & 24.12 \\
\hline Cooperation & 4.86 & 6.69 & 3.49 & 19.51 & 0.84 & 20.35 \\
\hline Rapport & 0.74 & 0.02 & 0.53 & 2.26 & 0.02 & 2.28 \\
\hline Diversity & 1.81 & 0.47 & 1.79 & 7.04 & 0.00 & 7.04 \\
\hline Exclusion & 1.69 & 1.26 & 1.29 & 6.29 & 0.01 & 6.30 \\
\hline Liberation & 0.79 & 0.01 & 0.89 & 3.38 & 0.01 & 3.39 \\
\hline
\end{tabular}

\section{Table III}

\section{Summary statistics for the main narrative choice categories}

\begin{tabular}{|l|c|c|c|c|}
\hline & Mean & Mode & SD & SE mean \\
\hline Activity & 48.00 & 51.16 & 1.619 & 0.282 \\
Optimism & 49.52 & 50.17 & 1.484 & 0.258 \\
Certainty & 44.89 & 29.66 & 4.897 & 0.853 \\
Realism & 46.80 & 45.78 & 1.862 & 0.324 \\
Commonality & 48.99 & 45.70 & 1.748 & 0.304 \\
\hline
\end{tabular}

interested parties of the company's commitment through optimistic words and words that show a sense of value. This indicates that there may have been a measure of bias in the way the report is presented to subtly manipulate readers' impressions of the company.

\section{Discussion and conclusions}

The results of this exploratory study indicate that narrative manipulation occurs in Mineral Resources and Mineral Reserves Reports through word choices that make the reports difficult to read and specific narrative selections, which bring in bias and may be a means to manipulate impressions. The lack of readability and use of specific narrative reduces the informational value of the reports. It disregards the requirement stated by Dominy et al. (2002) that reports should be presented in a way that considers the goals, background, and competencies of the company's various stakeholders, and is not in line with general principles of plain language as recommended by the SEC (1998).

One can argue that a Mineral Resources and Mineral Reserves Report is a technical report and is by nature a complex document requiring complex language. However, the general narrative of a Mineral Resources and Mineral Reserves Report should be written in a way to make it accessible to more stakeholders. Not only investors are interested in the information contained in these reports, but also others such as local communities. Some companies compensate employees with shares in the company, and thus employees are more likely to show an interest in the company's operations and performance through its corporate reports. Despite the fact that there will undoubtedly be advanced technical terms in a Mineral Resources and Mineral Reserves Report, the use of wordy items and passive voice sentences, of which there were many in the reports analysed, can cause confusion if not used cautiously or for a specific purpose. The excessive use of optimistic and Commonality words can also be considered bias or manipulation rather than necessity. 


\section{Supplementary Mineral Resources and Mineral Reserves Reports: Readability and textual choice}

The results from this study will be valuable to specifically the management and directors of mining companies, as they highlight a potential shortcoming in Mineral Resources and Mineral Reserves reporting that can be easily remedied. To ensure transparency and accountability to stakeholders, companies have a responsibility to present their published communications in a readable and unbiased format. The results from the study suggest that bodies such as the JSE and the SAMREC and SAMVAL Code committees need to pay attention to the narrative styles used in the corporate reports of mining companies. Tertiary institutions that teach students the art of report-writing ought to take cognisance of the principles of a clear, readable, and unbiased report. The results also provide evidence that stakeholders should be vigilant regarding the practices used in narrative reports and aware that the information they receive is not necessarily an objective view of the company's operations and position. Stakeholders with an important interest in a mining company could consider attending the training events that give more detail on the interpretation of Mineral Resources and Mineral Reserves statements in company reports.

The study has limitations, the first being the small sample size. Since companies started preparing IARs they also began to include Mineral Resources and Mineral Reserves information in them rather than providing it as supplementary documents. Future research could extract the Mineral Resources and Mineral Reserves sections from IARs in order to investigate a larger sample. Another limitation is that this study is confined to South Africa. It will be valuable to see whether Mineral Resources and Mineral Reserves Reports from other countries differ in their readability and narrative choice. Future research could explore the readability aspect in more detail and obtain users' inputs through surveys or reading experiments.

\section{References}

Alexa, M. and Zuell, C. 2000. Text analysis software: commonalities, differences and limitations: The results of a review. Quality and Quantity, vol. 34, no. 3. pp. 299-321. http://dx.doi.org/10.1023/A:1004740203542

Arena, C., Bozzolan, S., and Michelon, G. 2015. Environmental reporting: Transparency to stakeholders or stakeholder manipulation? An analysis of disclosure tone and the role of the board of directors. Corporate Social Responsibility and Environmental Management, vol. 22, no. 6. pp. 346-361. https://doi.org/10.1002/csr.1350

Barkemeyer, R., Comyns, B., Figge, F., and Napolitano, G. 2014. CEO statements in sustainability reports: Substantive information or background noise? Accounting Forum, vol. 38, no. 4. pp. 241-257. http://dx.doi.org/10.1016/j. accfor.2014.07.002

Bedeian, A.G. 2014. 'More than meets the eye': A guide to interpreting the descriptive statistics and correlation matrices reported in management research. Academy of Management Learning \& Education, vol. 13, no. 1. pp. 121-135. http://dx.doi.org/10.5465/amle.2013.0001

BöHLING, K., and MuRguíA, D. 2014. Sustainability reporting in the mining sector: Why institutional dynamics of reporting disappoint beliefs in its potentials for increased corporate accountability. Proceedings of the Fifth Biennial Conference of the European Consortium on Political Research Standing Group on Regulatory Governance on 'Regulatory Governance between Global and Local', IBEI, Barcelona, 25-27 June 2014. ECPR Standing Group on Regulatory Governance. European Consortium for Political Research, Colchester, UK.

Bonsall IV, S.B., Leone, A.J., Miller, B.P., and Rennekamp, K. 2017. A plain English measure of financial reporting readability. Journal of Accounting and Economics, vol. 63, no. 2-3. pp. 329-357. https://doi.org/10.1016/j. jacceco.2017.03.002
BonsALL, S.B., and MiLLer, B.P. 2017. The impact of narrative disclosure readability on bond ratings and the cost of debt. Review of Accounting Studies, vol. 22, no. 2. pp. 608-643. https://doi.org/10.1007/s11142-017-9388-0

Caglio, A., Melloni, G., and Perego, P. 2020. Informational content and assurance of textual disclosures: Evidence on Integrated reporting. European Accounting Review, vol. 29, no. 1. pp. 1-29. https://doi.org/10.1080/09638180.2019.16 77486

CAMILLERI, M.A. 2019. Theoretical insights on integrated reporting: Valuing the financial, social and sustainability disclosures. Integrated Reporting. CSR, Sustainability, Ethics \& Governance. Idowu, S.O. and Schmidpeter, R. (eds). Springer, Cham, Switzwelands. pp. 61-76.

Cho, C.H., Michelon, G., and PatTen, D.M. 2012. Impression management in sustainability reports: An empirical investigation of the use of graphs. Accounting and the Public Interest, vol. 12, no. 1. pp. 16-37. https://doi. org/10.2308/apin-10249

Cho, C.H., Roberts, R.W., and Patten, D.M. 2010. The language of US corporate environmental disclosure. Accounting, Organizations and Society, vol. 35, no. 4. pp. 431-443. https://doi.org/10.1016/j.aos.2009.10.002

Clatworthy, M. and Jones, M.J. 2001. The effect of thematic structure on the variability of annual report readability. Accounting, Auditing \& Accountability Journal, vol. 14, no. 3. pp. 311-326. http://dx.doi. org/10.1108/09513570110399890

CoURTIS, J.K. 1998. Annual report readability variability: tests of the obfuscation hypothesis. Accounting, Auditing \& Accountability Journal, vol. 11, no. 4. pp. 459-472. http://dx.doi.org/10.1108/09513579810231457

CoURTIS, J.K. 2004. Corporate report obfuscation: artefact or phenomenon? The British Accounting Review, vol. 36, no. 3. pp. 291-312. https://doi. org/10.1016/j.bar.2004.03.005

Criado-Jiménez, I., Fernández-Chulián, M., Larrinaga-González, C., and HusillosCARQués, F.J. 2008. Compliance with mandatory environmental reporting in financial statements: The case of Spain (2001-2003). Journal of Business Ethics, vol. 79, no. 3. pp. 245-262. https://doi.org/10.1007/s10551-0079375-7

DAUB, C.-H. 2007. Assessing the quality of sustainability reporting: an alternative methodological approach. Journal of Cleaner Production, vol. 15, no. 1. pp. 75-85. https://doi.org/10.1016/j.jclepro.2005.08.013

Davis, A.K., Piger, J.M., and Sedor, L.M. 2006. Beyond the numbers: An analysis of optimistic and pessimistic language in earnings press releases, vol. 5. Federal Reserve Bank of St. Louis, St Louis, MO.

De Villiers, C., Low, M., and Samkin, G. 2014. The institutionalisation of mining company sustainability disclosures. Journal of Cleaner Production, vol. 84, no. 1. pp. 51-58. http://dx.doi.org/10.1016/j.jclepro.2014.01.089

Diouf, D. and BoIRAL, O. 2017. The quality of sustainability reports and impression management: A stakeholder perspective. Accounting, Auditing \& Accountability Journal, vol. 30, no. 3. pp. 643-667. https://doi.org/10.1108/ AAAJ-04-2015-2044

Dominy, S.C., Noppé, M.A., and Annels, A E. 2002. Errors and uncertainty in mineral resource and ore reserve estimation: The importance of getting it right. Exploration and Mining Geology, vol. 11, no. 1-4. pp. 77-98. https://doi. org/10.2113/11.1-4.77

Du Tort, E. 2017. The readability of integrated reports. Meditari Accountancy Research, vol. 25, no. 4. pp. 629-653. https://doi.org/10.1108/ MEDAR-07-2017-0165

Emel, J., MaKene, M., and Wangari, E. 2012. Problems with reporting and evaluating mining industry community development projects: a case study from Tanzania. Sustainability, vol. 4, no. 2. pp. 257-277. https://doi.org/0.3390/su4020257

Eugene BaKer III, H. and KaRE, D.D. 1992. Relationship between annual report readability and corporate financial performance. Management Research NewS, vol. 15, no. 1. pp. 1-4. http://dx.doi.org/10.1108/eb028188 


\section{Supplementary Mineral Resources and Mineral Reserves Reports: Readability and textual choice}

Field, T. 2020. South African community wins right to access mining application. But who will win the war? The Conversation. https://theconversation.com/ south-african-community-wins-right-to-access-mining-application-but-whowill-win-the-war-147522

FLEsch, R. 1979. How to write plain English: Let's start with the formula. http:// pages.stern.nyu.edu/ wstarbuc/Writing/Flesch.htm [accessed 14 September 2020].

FonsECA, A. 2010. How credible are mining corporations' sustainability reports? A critical analysis of external assurance under the requirements of the international council on mining and metals. Corporate Social Responsibility and Environmental Management, vol. 17, no. 6. pp. 355-370. https://doi. org/10.1002/csr.230

Freeman, R. 1984. Strategic Management: A Stakeholder Approach. Pitman, Boston, MA.

HART, R. 2000. Diction 5.0: The text analysis program. Sage, Thousand Oaks, CA.

HaRT, R., and CARroll, C. 2013. Diction 7: The text analyses program. Digitext, Austin, TX.

HaSAn, M.M. 2018. Readability of narrative disclosures in 10-K reports: Does managerial ability matter? European Accounting Review, vol. 29, no. 1. pp. 1-22. https://doi.org/10.1080/09638180.2018.1528169

Hassan, A. 2019. Verbal tones in sustainability assurance statements: An empirical exploration of explanatory factors. Sustainability Accounting, Management and Policy Journal, vol. 10, no. 3. https://doi.org/10.1108/SAMPJ-06-2017-0051

HooghiEMSTRA, R. 2000. Corporate communication and impression management-new perspectives why companies engage in corporate social reporting. Journal of Business Ethics, vol. 27, no. 1. pp. 55-68.

Huang, X., Teоh, S. H., and Zhang, Y. 2014. Tone management. The Accounting Review, vol. 89, no. 3, pp. 1083-1113. https://doi.org/10.2308/accr-50684

Jones, M., Melis, A., GAIA, S., and AResu, S. 2017. Impression management and retrospective sense-making in corporate annual reports: Banks' graphical reporting during the global financial crisis. International Journal of Business Communication, vol. 57, no. 4. pp. 1-23. https://doi. org/10.1177/2329488417712010

KLARE, G.R. 1974. Assessing readability. Reading Research Quarterly, vol. 10, no. 1. pp. 62-102.

Lambert, R., Leuz, C., and VerRecchia, R. E. 2007. Accounting information, disclosure, and the cost of capital. Journal of Accounting Research, vol. 45, no. 2, pp. 385-420. https://doi.org/10.1111/j.1475-679X.2007.00238.x

LASkin, A.V. 2018. The narrative strategies of winners and losers: Analyzing annual reports of publicly traded corporations. International Journal of Business Communication, vol. 55, no. 3. pp. 338-356. https://doi. org/10.1177/2329488418780221

LI, F. 2008. Annual report readability, current earnings, and earnings persistence. Journal of Accounting and Economics, vol. 45, no. 2. pp. 221-247. https://doi. org/10.1016/j.jacceco.2008.02.003

LoughrAn, T. and McDonALD, B. 2014. Measuring readability in financial disclosures. Journal of Finance, vol. 69, no. 4. pp. 1643-1671. https://doi.org/10.1111/ jofi.12162

Loughran, T. and McDonald, B. 2016. Textual analysis in accounting and finance: A survey. Journal of Accounting Research, vol. 54, no. 4. pp. 1187-1230. https:// doi.org/10.1111/1475-679X.12123

Maubane, P., Prinsloo, A., and van Rooyen, N. 2014. Sustainability reporting patterns of companies listed on the Johannesburg securities exchange. Public Relations Review, vol. 40, no. 2. pp. 153-160. http://dx.doi.org/10.1016/j. pubrev.2014.02.014
MerkL-Davies, D.M. and Brennan, N.M. 2007. Discretionary disclosure strategies in corporate narratives: incremental information or impression management? Journal of Accounting Literature, vol. 27, no. 1, pp. 116-196.

Merkl-Davies, D.M. and Brennan, N.M. 2011. A conceptual framework of impression management: new insights from psychology, sociology and critical perspectives. Accounting and Business Research, vol. 41, no. 5. pp. 415-437. https://doi.org /10.1080/00014788.2011.574222

Montevirgen, K. 2016. 10 Lessons learned from the SEC plain English handbook. The Content Wrangler, 12 May 2016. https://thecontentwrangler. com/2016/05/12/10-lessons-learned-sec-plain-english-handbook/

NGWAKWE, C.C. and MtswenI, S.T. 2016. Extent of sustainability assurance in South African mining companies. Journal of Accounting and Management, vol. 6 , no. 1. pp. 59-74.

Noppé, M. 2014. Communicating confidence in Mineral Resources and Mineral Reserves. Journal of the Southern African Institute of Mining and Metallurgy, vol. 114 , no. 3. pp. 213-213.

O'Donovan, G. 2002. Environmental disclosures in the annual report. Accounting, Auditing \& Accountability Journal, vol. 15, no. 3. pp. https://doi. org/10.1108/09513570210435870

Ober, S., Zhao, J.J., Davis, R., and Alexander, M.W. 1999. Telling it like it is: The use of certainty in public business discourse. Journal of Business Communication, vol. 36, no. 3. pp. 280-296. https://doi.org/10.1177/002194369903600304

Rutherford, B.A. 2003. Obfuscation, textual complexity and the role of regulated narrative accounting disclosure in corporate governance. Journal of Management and Governance, vol. 7, no. 2. pp. 187-210.

SAMREC. 2016. South African Mineral Resource Committee. The South African Code for the Reporting of Exploration Results, Mineral Resources and Mineral Reserves (the SAMREC Code). 2016 Edition. http://www.samcode.co.za/codes/ category/8-reporting-codes?download=120:samrec

SAMVAL. 2016. South African Mineral Asset Valuation Committee (SAMVAL) Working Group. The South African Code for the Reporting of Mineral Asset Valuation (The SAMVAL Code), 2016 Edition as amended1 20 December 2016. http://www.samcode.co.za/codes/category/8-reportingcodes? download=120: samrec

SEC. 1998. A plain English handbook: How to create clear SEC disclosure documents. https://www.sec.gov/pdf/handbook.pdf [accessed 4 November 2020].

Smeuninx, N., De Clerck, B., and AerTs, W. 2020. Measuring the readability of sustainability reports: A corpus-based analysis through standard formulae and NLP. International Journal of Business Communication, vol. 57, no. 1. pp. 52-85. https://doi.org/10.1177/2329488416675456

South AfricA. 2019. About SA: South Africa's people. https://www.gov.za/about-sa/ south-africas-people [accessed 1 November 2020].

StacchezzinI, R., Melloni, G., and Lai, A. 2016. Sustainability management and reporting: the role of integrated reporting for communicating corporate sustainability management. Journal of Cleaner Production, vol. 136, no. 1. pp. 102-110.http://dx.doi.org/10.1016/j.jclepro.2016.01.109

SydserfF, R. and WeEtman, P. 1999. A texture index for evaluating accounting narratives: An alternative to readability formulas. Accounting, Auditing \& Accountability Journal, vol. 12, no. 4. pp. 459-488. http://dx.doi. org/10.1108/09513579910283503

Zhou, S., Simnett, R., and Green, W. 2017. Does integrated reporting matter to the capital market? Abacus, vol. 53, no. 1. pp. 94-132. https://doi.org/10.1111/ abac. 12104 


\section{Appendix}

\begin{tabular}{|c|c|}
\hline Narrative strategy & Definition \\
\hline Certainty & {$[$ Tenacity + Levelling + Collectives + Insistence $]-[$ Numerical Terms + Ambivalence + Self-reference + Variety $]$} \\
\hline Tenacity & $\begin{array}{l}\text { All uses of the verb to be (is, am, will, shall) three definitive verb forms (has, must, do) and their variants, as well as all associated contraction,s } \\
\text { (he'll, they've, ain't). These verbs connote confidence and totality. }\end{array}$ \\
\hline Levelling & $\begin{array}{l}\text { Words used to ignore individual differences and to build a sense of completeness and assurance. Included are totalizing terms (everybody, } \\
\text { anyone, each, fully), adverbs of permanence (always, completely, inevitably, consistently), and resolute adjectives (unconditional, consummate, } \\
\text { absolute, open-and-shut). }\end{array}$ \\
\hline Collectives & $\begin{array}{l}\text { Singular nouns connoting plurality that function to decrease specificity: These words reflect a dependence on categorical modes of thought. } \\
\text { Included are social groupings (crowd, choir, team, humanity), task groups (army, congress, legislature, staff), and geographical entities (county, } \\
\text { world, kingdom, republic). }\end{array}$ \\
\hline Insistence & $\begin{array}{l}\text { This is a measure of code-restriction and semantic contentedness. The assumption is that repetition of key terms indicates a preference for a } \\
\text { limited, ordered world. }\end{array}$ \\
\hline Numerical terms & $\begin{array}{l}\text { Any sum, date, or product specifying the facts in each case. This dictionary treats each isolated integer as a single word and each separate group } \\
\text { of integers as a single word. In addition, the dictionary contains common numbers in lexical format (one, tenfold, hundred, zero) as well as terms } \\
\text { indicating numerical operations (subtract, divide, multiply, percentage) and quantitative topics (digitize, tally, mathematics). }\end{array}$ \\
\hline Ambivalence & $\begin{array}{l}\text { Words expressing hesitation or uncertainty, implying a speaker's inability or unwillingness to commit to the verbalization being made. Included } \\
\text { are hedges (allegedly, perhaps, might), statements of inexactness (almost, approximate, vague, somewhere), and confusion (baffled, puzzling, } \\
\text { hesitate). Also included are words of restrained possibility (could, would, he'd) and mystery (dilemma, guess, suppose, seems). }\end{array}$ \\
\hline Self-reference & $\begin{array}{l}\text { All first-person references, including I, l'd, l'll, I'm, I've, me, mine, my, myself. Self-references are treated as acts of indexing whereby the locus of } \\
\text { action appears to reside in the speaker and not in the world at large thereby implicitly acknowledging the speaker's limited vision. }\end{array}$ \\
\hline Variety & $\begin{array}{l}\text { This measure conforms to Wendell Johnson's (1946) Type-Token Ratio, which divides the number of different words in a passage by the } \\
\text { passage's total words. A high score indicates a speaker's avoidance of overstatement and a preference for precise, molecular statements. }\end{array}$ \\
\hline Optimism & [Praise + Satisfaction + Inspiration] $-[$ Blame + Hardship + Denial $]$ \\
\hline Praise & $\begin{array}{l}\text { Affirmations of a person, group, or abstract entity. Included are terms isolating important social qualities (dear, delightful, witty), physical qualities } \\
\text { (mighty, handsome, beautiful), intellectual qualities (shrewd, bright, vigilant, reasonable), entrepreneurial qualities (successful, conscientious, } \\
\text { renowned), and moral qualities (faithful, good, noble). }\end{array}$ \\
\hline Satisfaction & $\begin{array}{l}\text { Terms associated with positive affective states (cheerful, passionate, happiness), with moments of undiminished joy (thanks, smile, welcome) and } \\
\text { pleasurable diversion (excited, fun, lucky), or with moments of triumph (celebrating, pride, auspicious). Also included are words of nurturance: } \\
\text { healing, encourage, secure, relieved. }\end{array}$ \\
\hline Inspiration & $\begin{array}{l}\text { Abstract virtues deserving of universal respect. Most of the terms in this dictionary are nouns isolating desirable moral qualities (faith, honesty, } \\
\text { self-sacrifice, virtue) as well as attractive personal qualities (courage, dedication, wisdom, mercy). Social and political ideals are also included: } \\
\text { patriotism, success, education, justice. }\end{array}$ \\
\hline Blame & $\begin{array}{l}\text { Terms designating social inappropriateness (mean, naive, sloppy, stupid) as well as downright evil (fascist, bloodthirsty, repugnant, malicious) } \\
\text { compose this dictionary. In addition, adjectives describing unfortunate circumstances (bankrupt, rash, morbid, embarrassing) or unplanned } \\
\text { vicissitudes (weary, nervous, painful, detrimental) are included. The dictionary also contains outright denigrations: cruel, illegitimate, offensive, } \\
\text { miserly. }\end{array}$ \\
\hline Hardship & $\begin{array}{l}\text { This dictionary contains natural disasters (earthquake, starvation, tornado, pollution), hostile actions (killers, bankruptcy, enemies, vices) and } \\
\text { censurable human behaviour (infidelity, despots, betrayal). It also includes unsavoury political outcomes (injustice, slavery, exploitation, rebellion) } \\
\text { as well as normal human fears (grief, unemployment, died, apprehension) and incapacities (error, cop-outs, weakness). }\end{array}$ \\
\hline Denial & $\begin{array}{l}\text { A dictionary consisting of standard negative contractions (aren't, shouldn't, don't), negative-functions words (nor, not, nay), and terms designating } \\
\text { null sets (nothing, nobody, none). }\end{array}$ \\
\hline Activity & [Aggression + Accomplishment + Communication + Motion] $-[$ Cognition + Passivity + Embellishment $]$ \\
\hline Aggression & $\begin{array}{l}\text { A dictionary embracing human competition and forceful action. Its terms connote physical energy (blast, crash, explode, collide), social } \\
\text { domination (conquest, attacking, dictatorships, violation), and goal-directedness (crusade, commanded, challenging, overcome). In addition, } \\
\text { words associated with personal triumph (mastered, rambunctious, pushy), excess human energy (prod, poke, pound, shove), disassembly } \\
\text { (dismantle, demolish, overturn, veto), and resistance (prevent, reduce, defend, curbed) are included. }\end{array}$ \\
\hline Accomplishment & $\begin{array}{l}\text { Words expressing task-completion (establish, finish, influence, proceed) and organized human behaviour (motivated, influence, leader, manage). } \\
\text { Includes capitalistic terms (buy, produce, employees, sell), modes of expansion (grow, increase, generate, construction) and general functionality } \\
\text { (handling, strengthen, succeed, outputs). Also included is programmatic language: agenda, enacted, working, leadership. }\end{array}$ \\
\hline Communication & $\begin{array}{l}\text { Terms referring to social interaction, both face-to-face (listen, interview, read, speak) and mediated (film, videotape, telephone, e-mail). The } \\
\text { dictionary includes both modes of intercourse (translate, quote, scripts, broadcast) and moods of intercourse (chat, declare, flatter, demand). } \\
\text { Other terms refer to social actors (reporter, spokesperson, advocates, preacher) and a variety of social purposes (hint, rebuke, respond, } \\
\text { persuade). }\end{array}$ \\
\hline Motion & $\begin{array}{l}\text { Terms connoting human movement (bustle, job, lurch, leap), physical processes (circulate, momentum, revolve, twist), journeys (barnstorm, jaunt, } \\
\text { wandering, travels), speed (lickety-split, nimble, zip, whistle-stop), and modes of transit (ride, fly, glide, swim). }\end{array}$ \\
\hline Cognition & $\begin{array}{l}\text { Words referring to cerebral processes, both functional and imaginative: Included are modes of discovery (learn, deliberate, consider, compare) } \\
\text { and domains of study (biology, psychology, logic, economics). The dictionary includes mental challenges (question, forget, re-examine, } \\
\text { paradoxes), institutional learning practices (graduation, teaching, classrooms), as well as three forms of intellection: intuitional (invent, perceive, } \\
\text { speculate, interpret), rationalistic (estimate, examine, reasonable, strategies), and calculative (diagnose, analyse, software, fact-finding). }\end{array}$ \\
\hline
\end{tabular}




\section{Supplementary Mineral Resources and Mineral Reserves Reports: Readability and textual choice}

\section{Appendix}

\begin{tabular}{|c|c|}
\hline Narrative strategy & Definition \\
\hline Passivity & $\begin{array}{l}\text { Words ranging from neutrality to inactivity. Includes terms of compliance (allow, tame, appeasement), docility (submit, contented, sluggish), } \\
\text { and cessation (arrested, capitulate, refrain, yielding). Also contains tokens of inertness (backward, immobile, silence, inhibit) and disinterest } \\
\text { (unconcerned, nonchalant, stoic), as well as tranquillity (quietly, sleepy, vacation). }\end{array}$ \\
\hline Embellishment & $\begin{array}{l}\text { A selective ratio of adjectives to verbs based on David Boder's (1940) conception that heavy modification slows down a verbal passage by de- } \\
\text { emphasising human and material action. Embellishment is calculated according to the following formula: [Praise }+ \text { Blame }+1] \div[\text { Present Concern } \\
+ \text { Past Concern }+1] \text {. }\end{array}$ \\
\hline Realism & [Familiarity + Spatial Terms + Temporal Terms + Present Concern + Human Interest + Concreteness $]-[$ Past Concern + Complexity $]$ \\
\hline Familiarity & $\begin{array}{l}\text { Consists of a selected number of C. K. Ogden's (1968) operation words, which he calculates to be the most familiar words in the English } \\
\text { language. Included are common prepositions (across, over, through), demonstrative pronouns (this, that), and interrogative pronouns (who, what } \\
\text { and a variety of particles, conjunctions, and connectives (a, for, so). }\end{array}$ \\
\hline Spatial terms & $\begin{array}{l}\text { Terms referring to geographical entities, physical distances, and modes of measurement. Included are general geographical terms (abroad, } \\
\text { elbow-room, locale, outdoors) as well as specific ones (Ceylon, Kuwait, Poland). Also included are politically defined locations (county, fatherland } \\
\text { municipality, ward), points on the compass (east, southwest) and the globe (latitude, coastal, border, snowbelt), as well as terms of scale } \\
\text { (kilometre, map, spacious), quality (vacant, out-of-the-way, disoriented), and change (pilgrimage, migrated, frontier.) }\end{array}$ \\
\hline Temporal terms & $\begin{array}{l}\text { Terms that fix a person, idea, or event within a specific time interval, thereby signalling a concern for concrete and practical matters: The } \\
\text { dictionary designates literal time (century, instant, mid-morning) as well as metaphorical designations (lingering, seniority, nowadays). Also } \\
\text { included are calendrical terms (autumn, year-round, weekend), elliptical terms (spontaneously, postpone, transitional), and judgmental terms } \\
\text { (premature, obsolete, punctual). }\end{array}$ \\
\hline
\end{tabular}

Present concern

A selective list of present-tense verbs extrapolated from C. K. Ogden's list of general and picturable terms, all of which occur with great frequency in standard American English. The dictionary is not topic-specific but points instead to general physical activity (cough, taste, sing, take), social operations (canvass, touch, govern, meet), and task performance (make, cook, print, paint).

Human interest

An adaptation of Rudolf Flesch's notion that concentrating on people and their activities gives discourse a life-like quality. Included are standard personal pronouns (he, his, ourselves, them), family members and relations (cousin, wife, grandchild, uncle), and generic terms (friend, baby, human, persons).

Concreteness

A large dictionary possessing no thematic unity other than tangibility and materiality. Included are sociological units (peasants, African Americans, Catholics), occupational groups (carpenter, manufacturer, policewoman), and political alignments (Communists, congressman, Europeans). Also incorporated are physical structures (courthouse, temple, store), forms of diversion (television, football, CD-ROM), terms of accountancy (mortgage, wages, finances), and modes of transportation (airplane, ship, bicycle). In addition, the dictionary includes body parts (stomach, eyes, lips), articles of clothing (slacks, pants, shirt), household animals (cat, insects, horse) and foodstuffs (wine, grain, sugar), and general elements of nature (oil, silk, sand).

Past concern $\quad$ The past-tense forms of the verbs contained in the Present Concern dictionary.

Complexity $\quad$ A simple measure of the average number of characters-per-word in each input file. Borrows Rudolph Flesch's (1951) notion that convoluted phrasings make a text's ideas abstract and its implications unclear.

Commonality $\quad$ [Centrality + Cooperation + Rapport $]-[$ Diversity + Exclusion + Liberation]

Centrality

Terms denoting institutional regularities and/or substantive agreement on core values. Included are indigenous terms (native, basic, innate) and designations of legitimacy (orthodox, decorum, constitutional, ratified), systematicity (paradigm, bureaucratic, ritualistic), and typicality (standardized, matter-of-fact, regularity). Also included are terms of congruence (conformity, mandate, unanimous), predictability (expected, continuity, reliable), and universality (womankind, perennial, landmarks).

Cooperation

Terms designating behavioural interactions among people that often result in a group product. Included are designations of formal work relations (unions, schoolmates, caucus) and informal associations (chum, partner, cronies) to more intimate interactions (sisterhood, friendship, comrade) Also included are neutral interactions (consolidate, mediate, alignment), job-related tasks (network, detente, exchange), personal involvement (teamwork, sharing, contribute), and self-denial (public-spirited, care-taking, self-sacrifice).

Rapport

This dictionary describes attitudinal similarities among groups of people. Included are terms of affinity (congenial, camaraderie, companion), assent (approve, vouched, warrants), deference (tolerant, willing, permission), and identity (equivalent, resemble, consensus).

Diversity

Words describing individuals or groups of individuals differing from the norm. Such distinctiveness may be comparatively neutral (inconsistent, contrasting, nonconformist), but it can also be positive (exceptional, unique, individualistic) and negative (illegitimate, rabble-rouser, extremist). Functionally, heterogeneity may be an asset (far-flung, dispersed, diffuse) or a liability (factionalism, deviancy, quirky), as can its characterizations rare vs. queer, variety vs. jumble, distinctive vs. disobedient.

Exclusion

A dictionary describing the sources and effects of social isolation. Such seclusion can be phrased passively (displaced, sequestered) as well as positively (self-contained, self-sufficient) and negatively (outlaws, repudiated). Moreover, it can result from voluntary forces (secede, privacy) and involuntary forces (ostracise, forsake, discriminate) and from both personality factors (small-mindedness, loneliness) and political factors (rightwingers, nihilism). Exclusion is often a dialectical concept: hermit vs. derelict, refugee vs. pariah, discard vs. spurn).

Liberation

Terms describing the maximizing of individual choice (autonomous, open-minded, options) and the rejection of social conventions (unencumbered, radical, released). Liberation is motivated by both personality factors (eccentric, impetuous, flighty) and political forces (suffrage, liberty, freedom, emancipation) and may produce dramatic outcomes (exodus, riotous, deliverance) or subdued effects (loosen, disentangle, outpouring). Liberatory terms also admit to rival characterizations: exemption vs. loophole, elope vs. abscond, uninhibited vs. outlandish. 